\title{
Effect of Post Harvest Hexanal Treatment on Shelf Life of Guava
}

\author{
G.N. Ashitha ${ }^{1 *}$, P. Preetha ${ }^{2}$ and N. Varadharaju $^{3}$ \\ ${ }^{1}$ Dept of F\&AP, TNAU, AEC \& RI, Coimbatore, India \\ ${ }^{2} S R F, P H T C, A E C \& R I, T N A U$, Coimbatore, India \\ ${ }^{3}$ PHTC, AEC \& RI, TNAU, Coimbatore, India \\ *Corresponding author
}

\section{A B S T R A C T}

\section{Keywords}

Hexanal, TSS-Total soluble solids, Storage life

Article Info

Accepted:

10 June 2019

Available Online:

10 July 2019
Guava is highly perishable in nature, having shelf life only 2-3 days at ambient condition which is a concern during marketing and transportation. Hence a study was under taken to extend the shelf life of guava using a chemical named hexanal which is a chemical used to delay the ripening of fruits. Hexanal treatments such as $1200 \mu \mathrm{ll}^{-1}$ for $4.5 \mathrm{~h}, 1400 \mu \mathrm{ll}^{-1}$ for 3 $\mathrm{h}$ and $4.5 \mathrm{~h}$ and $1600 \mu \mathrm{ll}^{-1}$ for $3 \mathrm{~h}$ and $4.5 \mathrm{~h}$ had minimum change in texture and color. Hence these treatments were selected for further studies. Physiological loss in weight, $\mathrm{pH}$ and TSS of fruits increased during storage under both condition but the percent increase was found to be lesser than the control fruits. The hexanal treated fruits also had a higher retention of ascorbic acid as compared to control fruit. Comparing all the parameters analyzed in guava treated with hexanal and 1-MCP, this study suggest that hexanal treatment of $1400 \mu \mathrm{ll}^{-1}$ for $3 \mathrm{~h}$ and $4.5 \mathrm{~h}, 1600 \mu \mathrm{ll}^{-1}$ for $3 \mathrm{~h}$ and $4.5 \mathrm{~h}$ resulted in better retention of good texture, colour and all other quality parameters with 6 days of storage life in ambient and more than 20 days in a cold room.

\section{Introduction}

Guava (Psidium guajava L.), is an important fruit crop of the subtropical and tropical regions of the world belongs to Myrtaceae family. It is considered as common man's fruits and is called as the apple of the tropics. Guava is a super fruit contains high amounts of vitamins A, B2 (Riboflavin), B1 (Thiamine) and vitamin C. Guava contains about 2-5 times more vitamin $\mathrm{C}$ content than that of citrus fruit (Singh, 2005). It is a climacteric fruit, hence exhibit a burst in respiration and the production of ethylene during ripening (Brown and Wills, 1983; Bashir and Abu-Goukh, 2002). Usually the fruits are harvested at different stage of maturity, depending on the processing requirements. After reaching the physiological maturity, it ripens fast within 2 days resulting in early senescence of the fruit (Chundawat et al., 1976). It is very susceptible to mechanical damage, insect attack and fungal rots due to its soft and thinskin (Brown and Paxton, 1983).

Fruit ripening is associated with several metabolic and a physicochemical changes which includes the loss in firmness, cell 
membrane degradation which finally leads to senescence. PLD (Phospholipase D) is an enzyme which is one of the main components responsible for the dissociation of cell membrane structure. The PLD action is simulated during fruit ripening and accelerates towards senescence. Active site of PLD consists of two HKD motifs that hydrolyze phospholipid in a two step pingpong mechanism generating a phosphatidatePLD intermediate (Koonin, 1996). This complex in reaction with water or primary alcohol produces phosphatidic acid or phosphatidyl-alcohol. It was found that a primary alcohol such as hexanol and an aldehyde such as hexanal were potential inhibitors of PLD activity (Paliyath, 2008). Lack of hydroxyl group in hexanal interrupt the complete hydrolysis of substrate-enzyme intermediate.

There are many chemicals available commercially to control the ethylene biosynthesis. Hexanal is one such chemical used to delay the ripening of fruits. Hexanal is a C-6 aldehyde which is produced naturally via the lipoxygenase pathway in plants and is a precursor to the formation of alcohols and esters that operate in production of aroma (Hildebrand, 1989). Hexanal is considered as GRAS (Generally Regarded as Safe) compound for food use by US FDA (United States Food and Drug Administration).

Hexanal is also commercially available and is reported to inhibit spore germination of Pencillium expansum (Timothy Durance, 2013). Hexanal vapour also inhibited spore germination and mycelial growth in raspberries at concentration and time dependent manner (Song et al., 2007). Hexanal can be used to improve the safety of minimally processed apple slices (Lanciotti et al., 2003) and also responsible for the enhancement of aroma in apple slices (Song et al., 1996). Hexanal also changed the volatile compounds of strawberries (Misran et $a l ., 2015)$ and its vapour treatment in longan fruit reported to reduced fruit decay (Thavong et al., 2010).

Pre-harvest application of hexanal on guava fruit showed minimum fruit decay with improved quality (Gill et al., 2016). The post harvest application of hexanal delayed ripening and enhanced fruit quality much better than control in case of sweet cherries (Sharma et al., 2010) and has shown similar action in green house tomatoes (Utto et al., 2007).

Luknow-49 is one of the local varieties in the states of India, which is available in plenty. Unlike the other varieties of guava, this particular variety also ripens fast and has shelf life of just 2- 3 days. Hence, attempts were made to increase the shelf life of the guava fruit by treating with hexanal and 1-MCP for different concentrations and exposure time under two different storage conditions.

With the above background the study was conducted on the objective of studying the effect of post-harvest vapour treatment of hexanal on delaying ripening of guava (Lucknow 49) fruit and to evaluate the physico chemical parameters of the treated guava fruits.

\section{Materials and Methods}

Fresh dark green coloured guava fruit, variety: (Lucknow-49) that had attained around 90 per cent maturity was brought from Ayakkudi, Palani. After harvesting the guava fruits were kept in shade for $3 \mathrm{~h}$ to remove field heat and then subjected for research work. Guava fruits were washed in a water to remove all adhering dirt, dust, chemicals etc. and then shade dried, to remove surface moisture. 


\section{Hexanal vapour treatment of guava}

Guava fruits were treated with hexanal in vapour treatment chamber of $27 \mathrm{~L}$ Volume. The chamber had a separate sample holder for keeping petri dishes in which required quantity of hexanal to be produced is placed to get the calculated amount of hexanal vapour. Since there was no earlier research conducted on hexanal vapour treatment of guava fruit different Preliminary trials were conducted with different concentration and exposure time from $100 \mu 11^{-1}$ to $1400 \mu 11^{-1}$ for $1,2,3,4$ and 5 hours of studying the shelf life increase with respect to texture, colour values and respiration rate study. From these analyzed results, it was found that, above $1000 \mu \mathrm{ll}^{-1}$, especially $1400 \mu \mathrm{ll}^{-1}$ gave better results, hence concentrations of 1000, 1200, 1400 and $1600 \mu \mathrm{Il}^{-1}$ were selected for the experimental purpose.

In case of exposure time 3hours were found better. Hence the exposure time of hexanal vapour treatment fixed at $1.5,3$ and 4.5 hours respectively. Similar work was presented by Geeta et al., (2015) conducted hexanal vapour treatment for shelf life extension of mango using different concentration of 600,900 , and $1200 \mu 11-1$ and exposed to hexanal vapour for 2,4 , and 6 hours.

The shelf life of fruits was studied in both ambient $\left(20-35^{\circ} \mathrm{C}, 55-70 \% \mathrm{RH}\right)$. The study was conducted on the month of December and continued up to May so a wide variation in temperature.

\section{Evaluation of quality attributes}

Fruit firmness was measured with the help of a Texture Analyzer (TA-HDi, Stable Micro Systems, UK, Plate) (Camps et al., 1989). A 4 $\mathrm{mm}$ cylindrical probe $(\mathrm{P} / 4)$ was used with 2 $\mathrm{mm} \mathrm{s}{ }^{-1}$ pre-test speed, $0.1 \mathrm{~mm} / \mathrm{s}$ test speed and $10 \mathrm{~mm} / \mathrm{s}$ post-test speed up to $10 \mathrm{~mm}$ penetration depth. The physiological loss in weight (PLW) of fruit was determined on the basis of initial weight of the fruit and successive loss in weight that occurred during storage and expressed as percentage loss. The $\mathrm{pH}$ value was determined by using a digital $\mathrm{pH}$ meter (Systronics $\mu$ pH system 361, Ahmedabad, India). The total soluble solids (TSS) were determined using hand refractometer (Make, Erma) and TSS were expressed as ${ }^{\circ}$ Brix (Ranganna, 1991).The ascorbic acid content was estimated using the procedure of Sadasivam and Manickam, (1992) and expressed as mg $100 \mathrm{~g}^{-1}$ of fresh sample.

\section{Respiration studies}

Respiration measures the rate of metabolic activities in guava fruits and also indicates ripening of fruits. Glass bottles of $3.80 \mathrm{~L}$ capacity with metal lids were used for respiration studies. About one $\mathrm{kg}$ of fresh guava fruits, $1 \mathrm{~kg}$ of guava fruits exposed to hexanal vapour and $1 \mathrm{~kg}$ of guava fruits treated with 1-MCP gas were placed in glass bottles which were stored under atmospheric and cold storage conditions. For guavas stored in ambient condition, $\mathrm{O}_{2}$ and $\mathrm{CO}_{2}$ were measured at $1 \mathrm{~h}$ intervals using gas analyser (Dansensor-Checkmate III, as shown in Plate 3.5 ) and $12 \mathrm{~h}$ interval for guava fruits stored in cold room. The rate of respiration of guava fruits was determined using the following equation as reported by (Cameron et al., 1989).

\section{Statistical analysis}

Statistical analysis was carried out to study the effect of different parameters on all the selected variables. Analysis of variance (ANOVA) was conducted with Factorial Completely Randomized Design (FCRD) using the statistical software AGRES 


\section{Results and Discussion}

\section{The effect of hexanal on firmness of guava}

The effect of hexanal on firmness of guava during storage is shown in the Figure 1 Firmness decreased with storage period and the hexanal treated guava had a lesser decrease $(44 \%)$ in firmness compared to control (91\%). Samples treated with $1400 \mu 11^{-}$ ${ }^{1}$ for $3 \mathrm{~h}$ gave highest firmness of $23.12 \mathrm{~N}$ along with $1600 \mu \mathrm{Hl}^{-1}$ for $3 \mathrm{~h}, 4.5 \mathrm{~h}$ and 1400 $\mu \mathrm{ll}^{-1}$ for $4.5 \mathrm{~h}$ treatments had 20.78, 20.54, $19.76 \mathrm{~N}$ of firmness respectively after 8 days of storage under ambient condition.

Higher firmness in hexanal treated samples may be due to the delayed ripening of and reduced activity of enzyme phospholipase D in guava. Tiwari and Paliyath (2011); Cheema et al., (2014); Gill et al., (2015) and Sharma et al., (2010) also found similar results in guava and sweat cherries. The hexanal treatment (concentration and exposure time) had a significant $(\mathrm{p} \leq 0.01)$ effect on the firmness of guava during storage at both ambient and cold storage condition.

\section{Effect of hexanal on colour of guava}

The effect of hexanal on colour of guava during storage is shown in the Figure 2 through Figure 3. Colour values $\left(L^{*}, a^{*} b^{*}\right)$ of hexanal treated guava decrease with storage at both ambient $\left(20-35^{\circ} \mathrm{C}\right)$ and cold condition $\left(10 \pm 2^{\circ} \mathrm{C}\right)$. Change in colour values of $\mathrm{L}^{*}$ and $\mathrm{a}^{*}$ may be attributed to the lightness of fruits, losses of chlorophyll content on ripening and increment in $b^{*}$ value due to increase in carotenoids contents of guava fruit on ripening. At ambient condition, lesser decrease of $\mathrm{L}^{*}$ and $\mathrm{a}^{*}$ values was found in the treatment of $1400 \mu \mathrm{ll}^{-1}$ for $4.5 \mathrm{~h}$ and $1600 \mu \mathrm{Il}^{-1}$ for $3 \mathrm{~h}$ whereas in $\mathrm{b}^{*}$ value it was found to be in the treatment $1400 \mu 11-1,4.5 \mathrm{~h}$ with an increase of 22.31 per cent. The total colour difference for $1400 \mu \mathrm{ll}^{-1}$, for $3 \mathrm{~h}$ was found to be 17.01. The hexanal treatment (concentration and exposure time) had a significant $(p \leq 0.05)$ effect on the colour values $\left(L^{*}, a^{*}, b^{*}\right)$ of guava during storage at ambient storage condition.

\section{Effect of hexanal on respiration rate of guava}

The respiration rate of guava with respect to $\mathrm{CO}_{2}$ during storage is shown in the Figure 4 (a, b and c) During storage at ambient condition $\left(20-35^{\circ} \mathrm{C}\right)$, the respiration rate increased during the first 9 hours (respiration peak) and got reduced gradually. The hexanal treatment with $1600 \mu \mathrm{\mu l}^{-1}$ for $4.5 \mathrm{~h}$ guava had a minimum respiration rate of $54.40 \mathrm{ml} / \mathrm{Kg} \mathrm{h}$ $\mathrm{CO}_{2}$ under ambient condition whereas in cold storage, it was only $18.015 \mathrm{ml} / \mathrm{Kg} \mathrm{h}$.

The reduction in respiration rate of hexanal treatment may be due to delays in ripening induced by PLD inhibition. The PLD inhibition leads to a considerable reduction of membrane degradation process, hence the energy required by the fruit reduced and leads to reduced rates of respiration. The fruits treated with a small time interval for all concentration showed similar respiration rate trends as control fruits. This may be due to reduced absorption of hexanal on the fruit surface. Similar trend of results were reported by Gill et al., (2015) that the hexanal treatment reduced the respiration rate and transpiration water loss.

\section{Effect of hexanal on shelf life of guava during storage}

The guava treated with different concentration of 1000, 1200, 1400 and $1600 \mu \mathrm{ll}^{-1}$ and with exposure time of $1.5,3$ and $4.5 \mathrm{~h}$ retained better firmness and color with an average of $24 \mathrm{~N}$ and $\mathrm{L}^{*}(62.66), \mathrm{a}^{*}(-8.16)$ and $\mathrm{b} *(45.72)$ and had a lesser respiration rate $(59.02 \mathrm{ml} / \mathrm{kg}$ 
h) after 4 days of storage in ambient condition.

At ambient conditions, shelf life was extended up to 6 days. The fruits treated with hexanal showed a natural ripening process but in a delayed manner. High concentrations and short duration of exposure resulted in less change compared to higher concentration treatment for long time exposure time $(1400$,

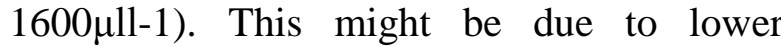
concentration were not enough to produce inhibition action of PLD enzyme. Fruits treated with higher concentration for short time also showed a lesser change because there is no enough time to vaporize whole hexanal liquid to vapour form, hence reduced the absorption of hexanal vapour on the surface of guava fruit.

The hexanal arrests the action of enzymes causing degradation (PLD- phospholipase D) which delayed the ripening. Hexanal is a naturally occurring aldehyde which acts as a phospholipase D inhibitor, initiates a series of catabolic cascades that lead to the eventual deterioration of the membrane. Similar results were reported for apple, cherry, peach, plum and vegetables (Paliyath and Murr, 2007; Sharma et al., 2010; Tiwari and Paliyath, 2011).

There are many quality parameters that decide the quality of fruits among them; texture and colour of fruit are considered to be a priority to attract consumers. From the experiments conducted using hexanal, best treatment among them were selected for further analysis of quality parameters. The selection was based on the treatments that gave higher retention of firmness and colour. The following treatments such as $1200 \mu \mathrm{Hl}^{-1}$ for 4.5 $\mathrm{h}, 1400 \mu \mathrm{ll}^{-1}$ for $3 \mathrm{~h}$ and $4.5 \mathrm{~h}$ and $1600 \mu \mathrm{ll}^{-1}$ for $3 \mathrm{~h}$ and $4.5 \mathrm{~h}$ of guava with hexanal vapour were selected based on the firmness colour and respiration rate.
Effect of hexanal on physiological loss in weight of guava during storage

The effect of hexanal on physiological loss in weight of guava during storage is shown in the Figure 5. Weight of the guava decreased with increase in storage period. Maximum of 11.75 per cent physiological loss in weight was obtained in control whereas in hexanal treated sample $\left(1600 \mu \mathrm{Il}^{-1}\right.$ for $\left.3 \mathrm{~h}\right)$ had a lesser loss of 5.05 per cent after 8 days of storage. The ambient stored fruits showed higher percentage of loss in weight which may be due to loss in water from the produce by respiration and transpiration. In hexanal treated fruits, less weight loss was noted because hexanal delayed the ripening and thus resulting in low metabolism.

Biochemical changes induced after the application of the hexanal vapour may have helped to preserve the membrane integrity and cell structure resulting in reduced catabolic processes and quality losses (Tiwari and Paliyath 2011; Paliyath and Subramanian 2008). Similar kind of results were observed in sweat cherries and tomato after hexanal application (Sharma et al., 2010; Cheema et al., 2014).

\section{Effect of hexanal on $\mathrm{pH}$ of guava during storage}

The effect of hexanal on $\mathrm{pH}$ of guava during storage is shown in the Figure 6. It was observed that the $\mathrm{pH}$ of hexanal treated guava ranged from 3.98 to 4.3 at ambient condition $\left(20-35^{\circ} \mathrm{C}\right)$. From the figure, it is clearly seen that there is only slight change of about 9.5 per cent at ambient after 8 days of storage. A lesser increase of $\mathrm{pH}$ was observed in the hexanal concentration of $1600 \mu 11-1$ for $4.5 \mathrm{~h}$ treatment at cold storage (5.9\%). This change in the guava may be due to lesser rate of respiration and metabolic activity (Cheema $e t$ al., 2014). 
Fig.1 Effect of hexanal on firmness of guava

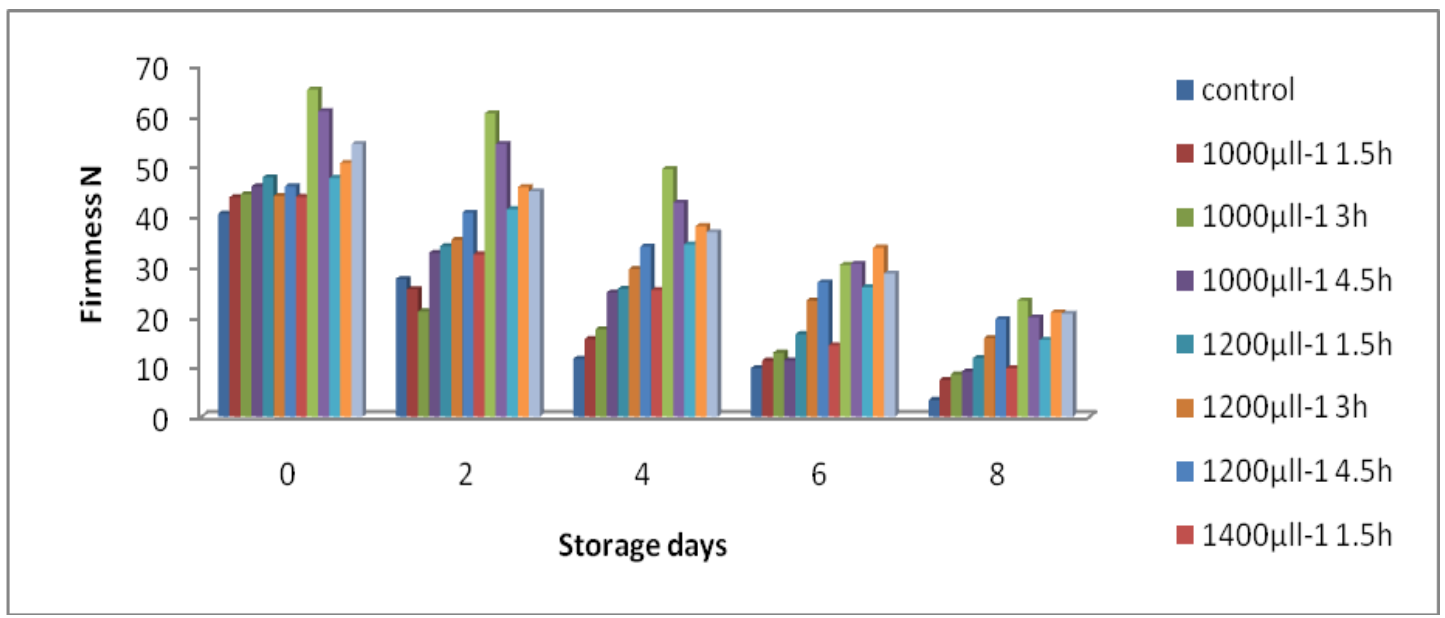

Fig.2 Effect of hexanal on $\mathrm{L}^{*}$ value of colour in guava

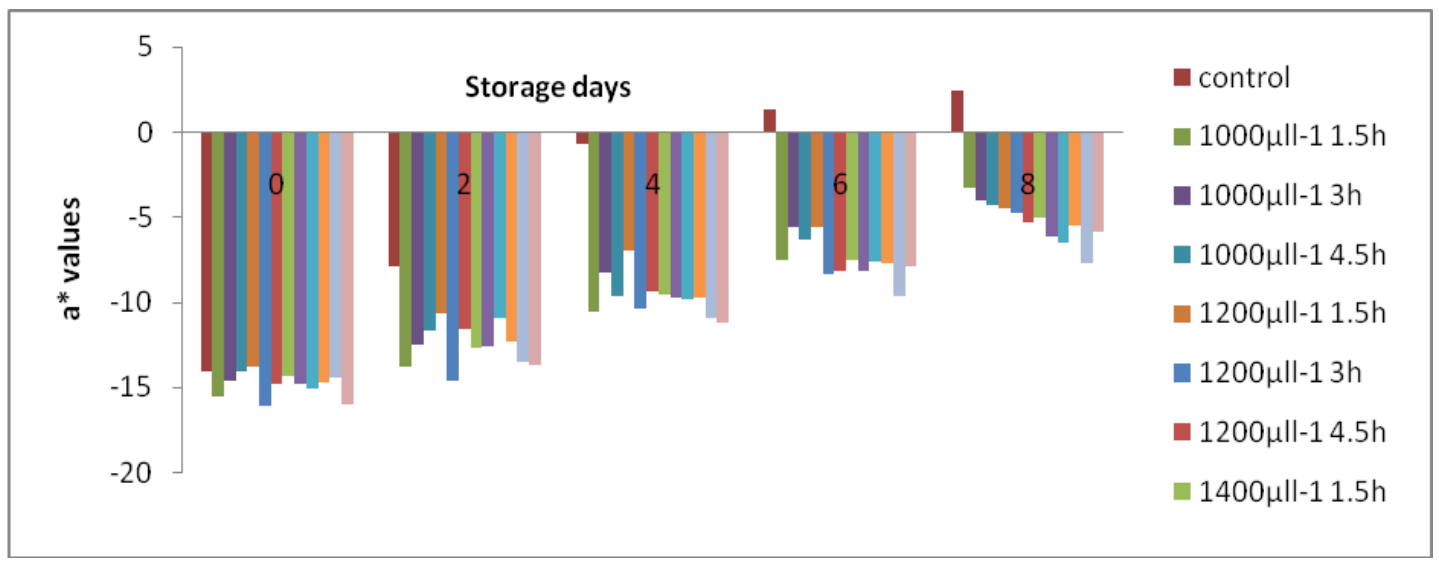

Fig.3 Effect of hexanal on a* value of colour in guava

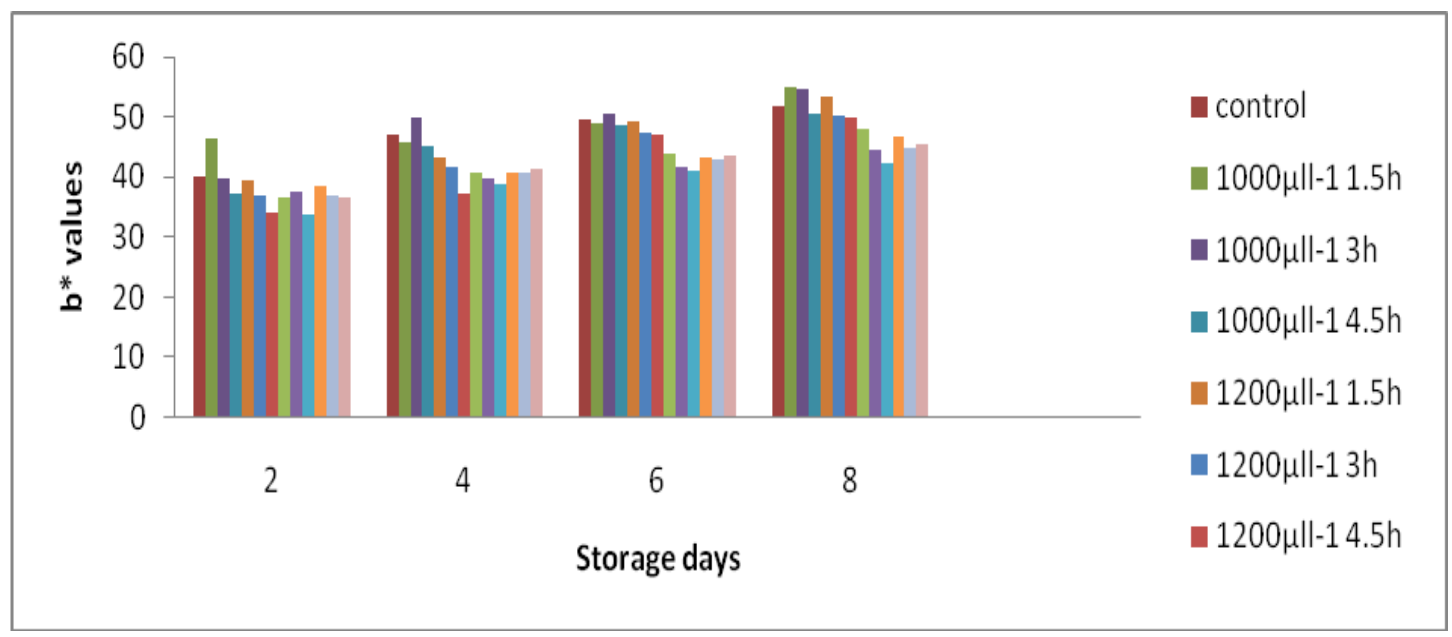


Fig.4 (a, b, c and d) Effect of hexanal on respiration rate of guava
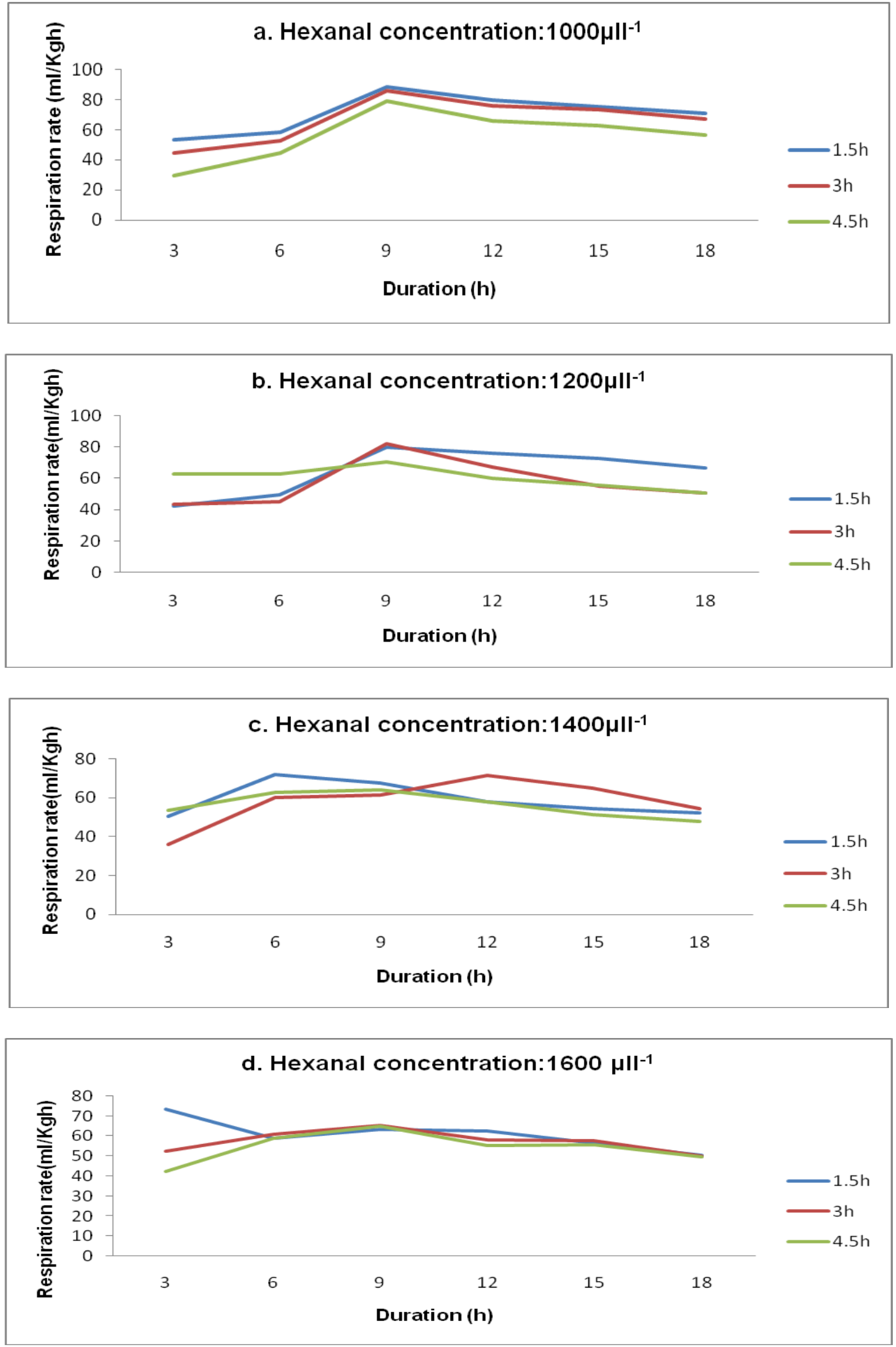
Fig.5 Effect of hexanal on physiological loss in weight of guava

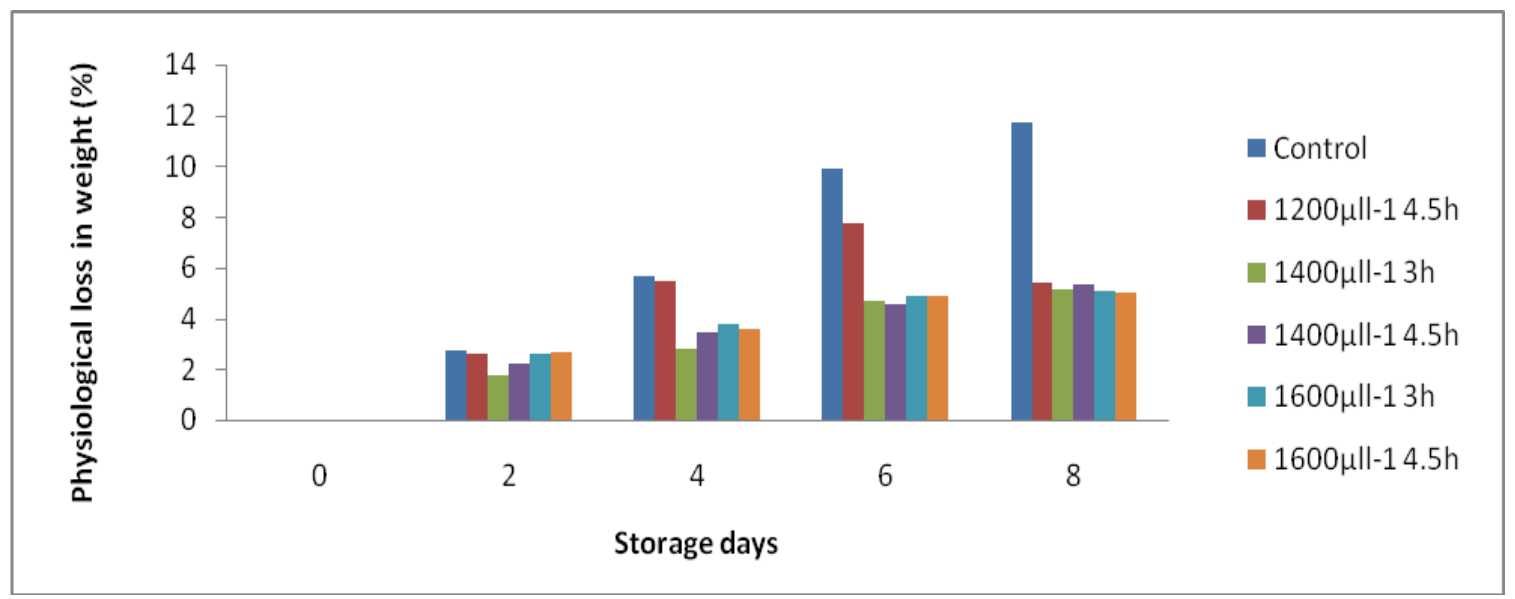

Fig.6 Effect of hexanal on $\mathrm{pH}$ of guava during storage

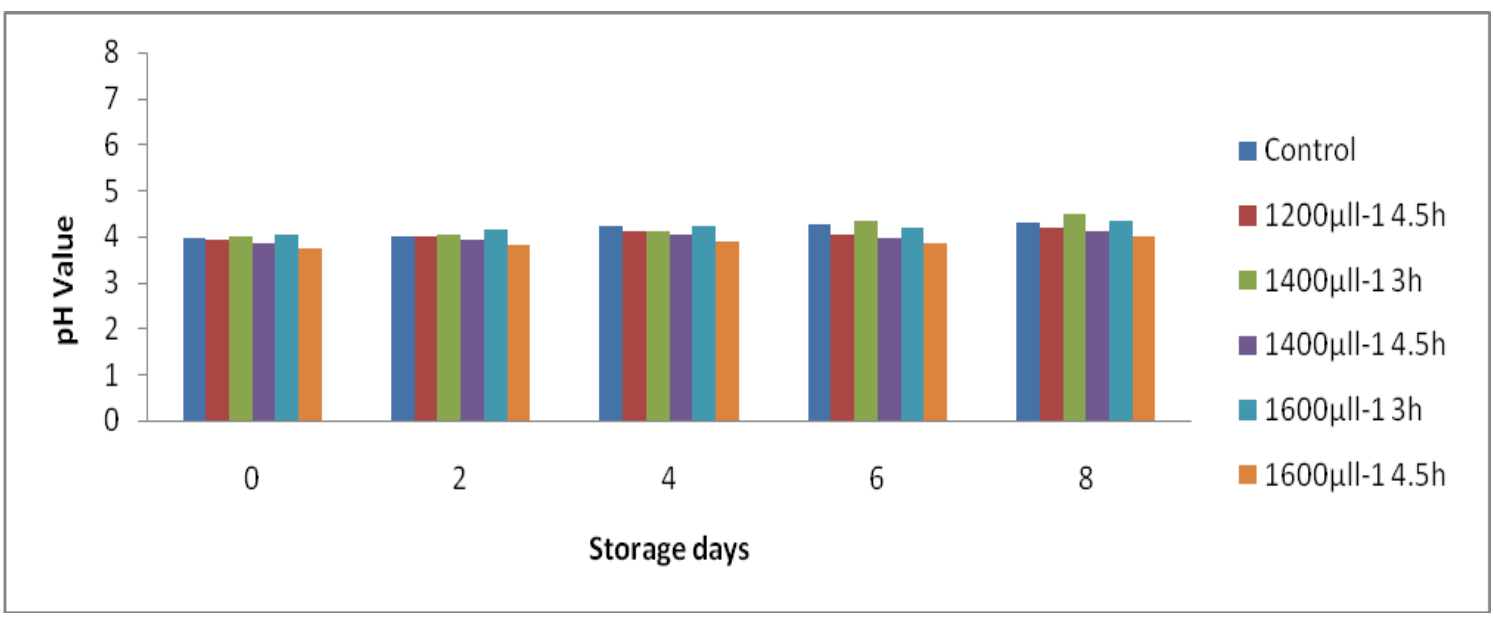

Fig.7 Effect of hexanal on TSS content of guava during storage

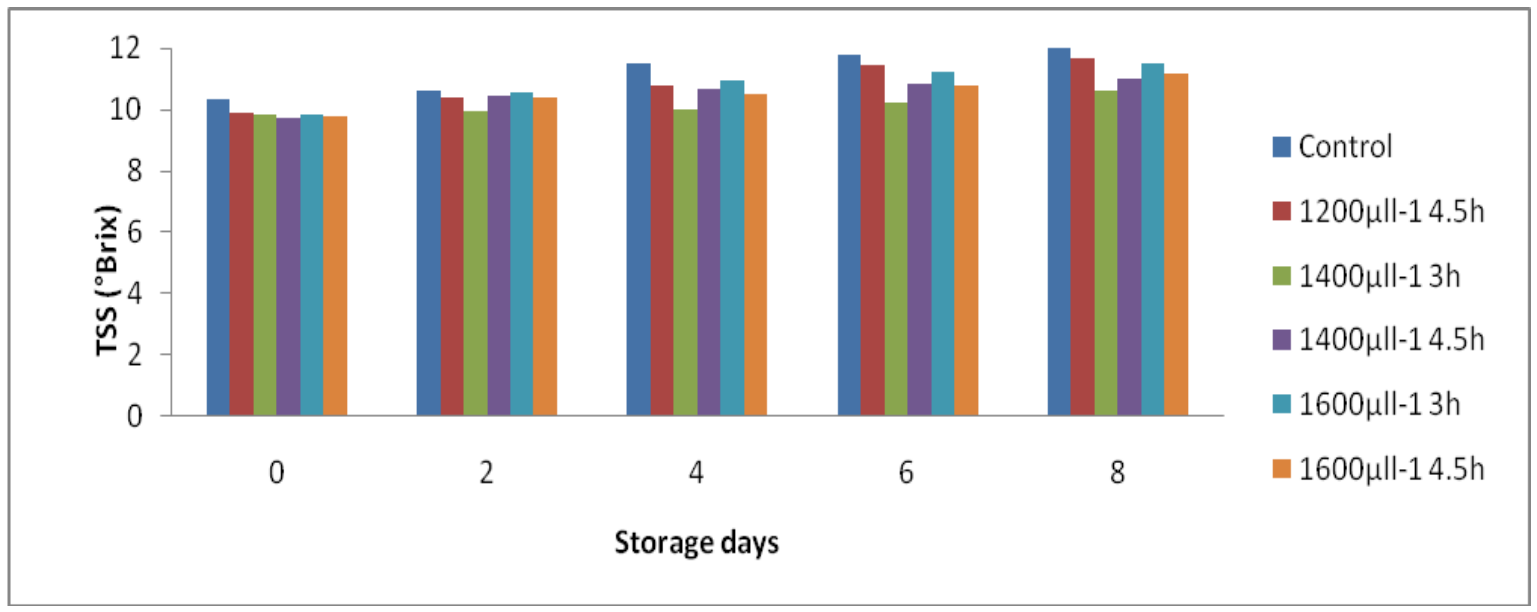


Fig.8 Effect of hexanal on ascorbic acid content of guava during storage

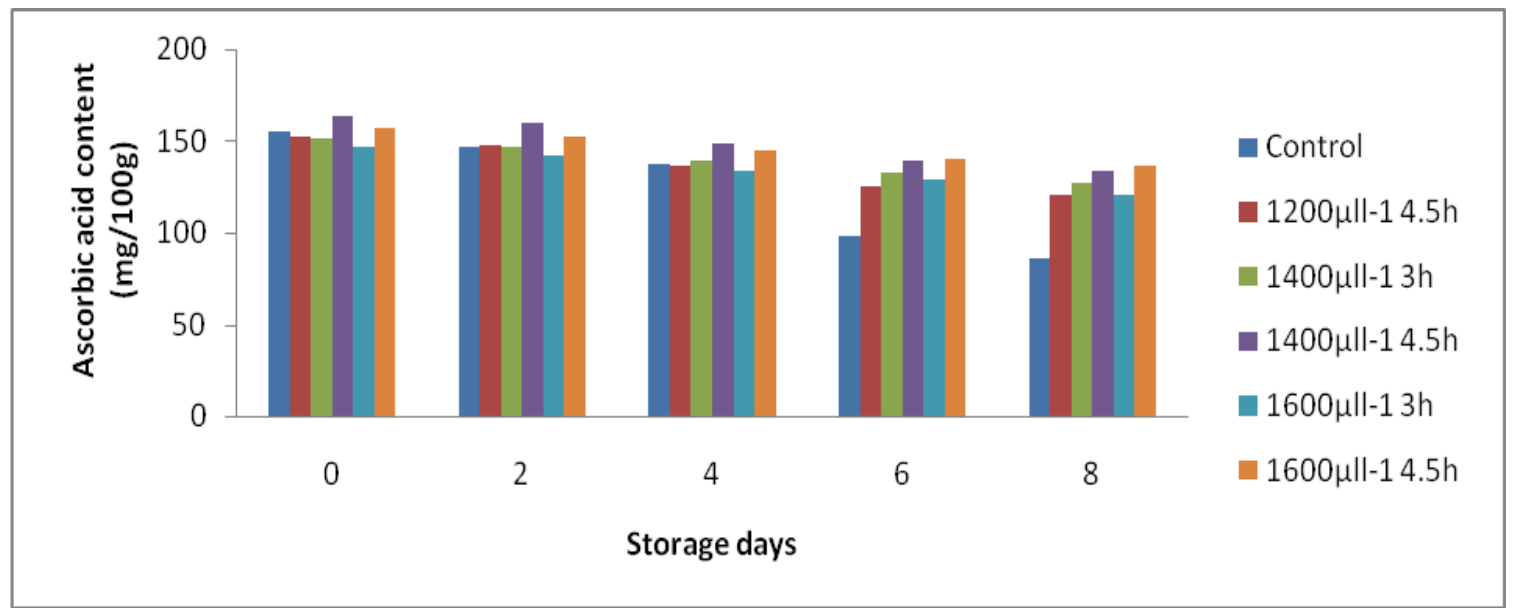

\section{Effect of hexanal on TSS of guava during storage}

The effect of hexanal on TSS of guava during storage is shown in the Figure 7. It was observed that the TSS of hexanal treated guava ranged from 9.77 to 11.68 at ambient condition $\left(20-35^{\circ} \mathrm{C}\right)$. TSS content increased to 16 percent in control sample, whereas in the hexanal treatment it was only 11 per cent and 12 per cent in hexanal concentration of $1400 \mu \mathrm{ll}^{-1}$ for $4.5 \mathrm{~h}$ and $1600 \mu \mathrm{ll}^{-1}$ for $4.5 \mathrm{~h}$ respectively. The maximum reduction was obtained in hexanal treated fruits with 1400 $\mu l l^{-1}$ for $3 \mathrm{~h}$.

The increase in TSS on storage may be due to the conversion of starch into simple sugars such as the glucose, fructose, and sucrose, thus causing changes in the flavour (increasing sweetness) (Esteves et al., 1982; Chitarra, 2005). These results were strongly in agreement with the results got with cherries (Wang and Vestrheim, 2002; Sharma et al., 2010).

\section{Effect of hexanal on ascorbic acid content of guava during storage}

The effect of hexanal on ascorbic acid content of guava during storage is shown in Figure 8 .
Ascorbic acid content decreases with storage period. The higher retention of ascorbic acid content in guava was $154.36 \mathrm{mg} / 100 \mathrm{~g}$ in $\mathrm{H}_{9}$ treatment at cold storage followed by 120.45 $\mathrm{mg} / 100 \mathrm{~g}$ in $\mathrm{H}_{6}$ treatment under ambient conditions after 8 days of storage. The treated guava showed a reduction in a range of 13 , $16,18,19$ and $21 \%$ in the treatments 1200 $\mu 11^{-1}$ for $4.5 \mathrm{~h}, 1400 \mu \mathrm{ll}^{-1}$ for $3 \mathrm{~h}, 1600 \mu \mathrm{ll}^{-1}$ for 3 and $4.5 \mathrm{~h}$ respectively.

The rapid decrease in the ascorbic acid content in the ambient may be due to the onset of ripening which led to the neutralization of acids to form sugars, thereby decreasing the ascorbic acid level. The results were in accordance with those reported by (Mapson, 1970 and Singh et al., 2005) in guava treated with hexanal spray. The treated fruits had an ascorbic acid content of 25.57 $\mathrm{mg} / 100 \mathrm{~g}$ compared to $6.70 \mathrm{mg} / 100 \mathrm{~g}$ in control fruits after 10 days of storage in guava at ambient condition (Gill et al., 2015).

The present study has shown that guava fruit treated with postharvest vapour treatment of hexanal at different concentrations and exposure times of $1400 \mu \mathrm{ll}^{-1}$ for $3 \mathrm{~h}$ and $4.5 \mathrm{~h}$, $1600 \mu 11^{-1}$ for $3 \mathrm{~h}$ and $4.5 \mathrm{~h}$ and stored in CFB boxes most efficiently retained the fruit quality attributes up to 8 days during ambient 
temperature at $20-35^{\circ} \mathrm{C}, 55-70 \% \mathrm{RH}$. The present study on guava, further confirms the results from previous, and currently ongoing studies on hexanal vapour treatment combined with modified atmospheric packaging and other packaging methods for extending the shelf life and maintaining or improving the quality characteristics in harvested fruit.

\section{References}

Bashir, H. A., Abu-Goukh, A. 2002. Compositional changes during guava fruit ripening. Journal of Food Chemistry, 80: 557-563.

Brown, B.I and R.B.H. Wills. 1983. Postharvest changes in guava fruit of different maturity. Scientia Horticulturae, 19, 237-243.

Brown, Bl. and B. Y. Paxton. 1983. Fresh market possibilities for guava fruit. Food Technology in Australia, 35(6): 288-290

Cameron AC, Boylan-Pett W, Lee J (1989) Design of modified atmo- sphere packaging systems: modeling oxygen concentrations with- in sealed packages of tomato fruits. Journal of Food Science, 54:1413-1421

Camps, C., P. Guillermin, J. C. Mauget and D. Bertrand. 2005. Data analysis of penetrometric force/displacement curves for the characterization of whole apple fruits. Journal of Texture Studies, 36:387-401

Cheema, A., P. Padmanabhan, J. Subramanian, T. Blom and G. Paliyath. 2014. Improving quality of greenhouse tomato (Solanum lycopersicum L.) by pre- and postharvest applications of hexanal containing formulations. Postharvest Biology and Technology, 95:13-19.

Chitarra, M. I. F. and A. B. Chitarra. 2005. Pós-colheita de frutas e hortaliças: fisiologia e manejo. 2. ed. Lavras: UFLA, 785.

Chundawat, B.S., J.P. Singh, R. Kainsa and O.P. Gupta. 1976. Post harvest studies on guava fruits: Effect of packing and storage period on quality of fruits. Journal of Horticultural Science. 5: 130-136.

Esteves, M. T. C., V. D. Carvalho, 1982. Modificações nos teores de amido, açúcares e grau de doçura de frutos de seis cultivares de goiabeira (Psidium guajava L.) em diferentes estádios de maturação. Ciência e Prática,. 6. 208218.

Geetha V., V. Thirupathi, N. Varadharaju, S. Ganapathy, D. Malathi and G.J. Janavi. 2015. Studies on effect of hexanal on shelf life of mango. Unpublished phd Thesis. Dept. of F\&APE. TNAU. Coimbatore.

Gill, K. S., Dhaliwal, H. S., Mahajan, B. V. C., Paliyath, G., and Boora, R. S. (2016). Postharvest Biology and Technology Enhancing postharvest shelf life and quality of guava (Psidium guajava L.) cv. Allahabad Safeda by pre-harvest application of hexanal containing aqueous formulation. Postharvest Biology and Technology, 112, 224-232.

Hildebrand, D.F. 1989. Lipoxygenases. Physiology Plant Physiology, 76:24925321

Koonin, E.V. 1996. A duplicated catalytic motif in a new superfamily of phospho- hydrolases and phospholipid synthases that includes poxvirus envelope proteins, Trends in Biochemical Sciences, 187: 567-676

Lanciotti, R., M.R. Corbo, F. Gardini, M.Sinigaglia and M.E. Guerzoni. 1999. Effect of hexanal on the shelf life of fresh apple slices. Journal of Agriculture and food science, 47:4769-4776. 
Mapson, C.W. 1970. Vitamins in Fruits: Stability of 1-Ascorbic acid in Biochemistry of Fruits and their Products. Academic Press, London, 376-387.

Misran, A., Padmanabhan, P., Sullivan, J.A., S. Khanizadeh, G. Paliyath. 2015. Composition of phenolics and volatiles in strawberry cultivars and influence of preharvest hexanal treatment on their profiles. Canadian Journal of Plant Science, 95: 115-126

Paliyath, G. and J.Subramanian. 2008. Phospholipase D inhibition technology for enhancing shelf life and quality In: Postharvest biology and technology of fruits, vegetables and flowers ed. by Paliyath, G., D.P. Murr, A.K. Handa and S. Lurie. Published by WileyBlackwell, USA. Pp. 240-245.

Paliyath, G. and Murr, D.P., 2007. Compositions for the preservation of fruits and vegetables. US Patent, 7198811.

Sadasivam, S. and A. Manickam. 1992. Biochemical methods for agricultural sciences. New Age International Publishers, pp. 184-186.

Sharma, M., J.K. Jacob, J. Subramanian and G. Paliyath. 2010. Hexanal and 1MCP treatments for enhancing the shelf life and quality of sweet cherry (Prunus avium L.). Scientia Horticultura, 125:239-247.

Singh, S., Singh, A.K., Joshi, H.K., 2005. Prolong storability of Indian
Gooseberry (Emblica officinalis Gaertn.) under semiarid ecosystem of Gujarat. Indian Journal of Agriculture. Science, 75: 647-650

Song, J., P.D. Hildebrand, L. Fan, F. Forney, W.E.Renderos, L. Campbell-Palmer and C. Doucette. 2007. Effect of Hexanal vapor on the growth of post harvest pathogens and Fruit decay. Journal of Food Science, 72(4): M108-M112.

Thavong, P., D.D. Archbold, T. Pankasemsuk and R. Koslanund. 2010. Effect of hexanal vapour on longan fruit decay, quality and phenolic metabolism during cold storage. International Journal of Food Science and Technology, 45: 2313-2320

Tiwari, K., and G. Paliyath, 2011. Plant Physiology and Biochemistry Microarray analysis of ripeningregulated gene expression and its modulation by 1-MCP and hexanal. Plant Physiology et Biochemistry. 49(3), 329-340.

Utto, W.; A.J. Mawson and J.E. Bronlund, 2007. Hexanal reduces infection of tomatoes by Botrytis cinerea whilst maintaining quality. Postharvest Biology and Technology. 47: 434-437.

Wang, L. and S. Vestrheim. 2002. Controlled atmosphere storage of sweet cherries (Prunus avium L.). Acta agriculturae, 52: $136-142$.

\section{How to cite this article:}

Ashitha, G.N., P. Preetha and Varadharaju, N. 2019. Effect of Post Harvest Hexanal Treatment on Shelf Life of Guava. Int.J.Curr.Microbiol.App.Sci. 8(07): 1057-1067. doi: https://doi.org/10.20546/ijcmas.2019.807.127 